\title{
Academic writing in higher education: focusing on courses of graduate programs of a public Brazilian university
}

\author{
Carlla Dall'Igna ${ }^{1}$ \\ Programa de Pós-Graduação em Inglês, Universidade Federal de Santa Catarina Universidade, \\ Florianópolis, SC, Brasil \\ Maria Ester Wollstein Moritz ${ }^{2}$ \\ Programa de Pós-Graduação em Inglês, Universidade Federal de Santa Catarina Universidade, \\ Florianópolis, SC, Brasil
}

\begin{abstract}
In the last twenty years researchers have been concerned with the development of higher education students writing literacy (CRISTOVÃO; VIEIRA, 2016; BAZERMAN; MORITZ, 2016). Approaches based on the new literacy studies (LEA; STREET, 1998) recognize the need to learn specific forms of acting in the academic context to successfully participate in such sphere. Considering the importance of academic writing in higher education, this research aims at investigating how academic writing literacy is approached in sixteen graduate programs at a public Brazilian university. One quarter of the university graduate programs were explored as a manner to find courses dealing with academic writing and the content organization of their course plans. Results showed that only fifty percent of the programs investigated offer courses on academic writing and each graduate program approaches academic writing literacy differently. It seems that writing practices in the academic context investigated are still not considered a major issue.
\end{abstract}

Keywords: Academic literacy; Graduate programs; Academic writing; Syllabus.

Título: Escrita acadêmica na universidade: um estudo de cursos de programas de pós-graduação de uma universidade pública brasileira

Resumo: Nos últimos 20 anos, pesquisadores têm se preocupado com o desenvolvimento do letramento acadêmico nas universidades (CRISTOVÃO; VIEIRA, 2016; BAZERMAN; MORITZ, 2016). As abordagens baseadas nos estudos dos novos letramentos (LEA; STREET, 1998; STREET, 2004) apontam para a necessidade de conhecer o processo de apropriação da escrita e leitura no contexto acadêmico de modo a facultar aos estudantes engajamento nas práticas desse contexto. Considerando a importância da escrita acadêmica na universidade, esta pesquisa objetiva investigar como o letramento da escrita acadêmica é abordado em dezesseis programas de pós-graduação de uma universidade pública brasileira. Um quarto dos programas foi investigado de modo a mapear as disciplinas que abordam escrita acadêmica e a investigar os seus conteúdos programáticos. Os resultados demonstram que apenas cinquenta por cento dos programas oferecem disciplinas que

\footnotetext{
${ }^{1}$ Mestre (Universidade Federal de Santa Catarina). Orcid: https://orcid.org/0000-0002-5905-843X

E-mail: carlla dalligna@hotmail.com

${ }^{2}$ Doutora (Universidade Federal de Santa Catarina), Universidade Federal de Santa Catarina. Orcid: https://orcid.org/0000-0001-9848-9171

E-mail: nicamoritz@yahoo.com
} 
incluem escrita acadêmica e cada disciplina aborda o letramento diferentemente. Parecenos que o desenvolvimento do letramento da escrita acadêmica ainda não é considerado importante nessa esfera acadêmica.

Palavras-chave: Letramento acadêmico; Programa de pós-graduação; Escrita acadêmica; Planos de curso.

\section{Introduction}

Students writing and the concern for improving academic writing have been the objects of a growing body of research (BAZERMAN; MORITZ, 2016; MARINKOVICH et al., 2016; RUSSEL, 1991). More specifically, it is acknowledged that a stronger systematic scholarly interest in reading and writing at Higher Educational level started the beginning of the 2000s (TAPIA-LADINO et al., 2016). Such interest is originated from the recognition that when entering the university context, students are required to possess a different kind of knowledge - the specialized one - which was not covered by initial literacy acquired during elementary and secondary school (MARINKOVICH et al., 2016; FERREIRA; LOUSADA, 2016; CRISTOVÃO; VIEIRA, 2016). Consequently, students need to learn new writing strategies to successfully participate in this higher education context.

The importance of learning such specific knowledge to act in this academic context is highlighted when a genre studies perspective is taken into consideration. Marcuschi (2002) points out that the appropriation of a genre does not involve only the knowledge about a linguistic form, but also the knowledge about how to act linguistically and achieve specific objectives in a given social situation. This perspective also includes the academic context, since it situates students in the social, cultural and epistemic context, that is, a new rhetorical situation - in this case, that of academic disciplines in undergraduate or graduate programs that requires the learning of a new discourse in order to act and respond to this social situation (MARINKOVICH et al., 2016).

Bearing in mind this need for appropriation of a new genre in the academic context, many authors refer to a research area named academic literacy (CARLINO, 2005; MARINKOVICH ET AL., 2016; FERREIRA; LOUSADA, 2016), also called writing studies in Higher Education by other authors (BAZERMAN et al., 2016; NAVARRO et al., 2016). Nourished by multiple theoretical-methodological traditions - discourse studies, applied linguistics, psychology, education sciences, and specific didactics -, this approach seeks to better understand the development and impact of studies on reading and writing in higher education (NAVARRO et al., in press). Following this tradition, it is also acknowledged in the area the role of teachers and educational institutions in the process of enculturation in this new context (CARLINO, 2013; MARINKOVICH et al., 2016). Teachers and institutional support, therefore, are seen as paramount to guide and help students in this learning process.

In an attempt to relate the importance of teaching academic writing and the actual reality of universities, many studies have been seeking to establish a diagnosis of the writing 
studies panorama in higher education, mainly concerning Latin America universities (BORK et al., 2014; BAZERMAN et al., 2016; MARINKOVICH et al., 2016; TAPIA-LADINO et al., 2016; CRISTOVÃO; VIEIRA, 2016). Following this trend and considering the importance of academic writing in higher education, this paper adds to existing research on the current panorama of writing studies in higher education by providing a diagnosis of the academic writing treatment in a Brazilian university. Specifically, the objective of the present study is to investigate how academic writing literacy is approached in sixteen graduate programs at Universidade Federal de Santa Catarina. By doing so, it is expected that we gain a better understanding of the strengths, weaknesses, and obstacles higher education academic writing faces in Brazil.

\section{Objective and research questions}

This research paper aims at investigating how academic writing literacy is approached in sixteen graduate programs at Universidade Federal de Santa Catarina. In order to reach such objective, the following research questions are addressed:

How is academic writing literacy approached in sixteen graduate programs at Universidade Federal de Santa Catarina?

Specific Questions:

1- Is there a specific academic writing course in each of the 16 graduate programs under investigation? If so, what is its nature (elective, mandatory, aiming master's/doctoral students)?

2- What aspects of academic writing are valued by the programs/courses investigated?

After presenting the introduction and main objectives of the present research, the next sessions present the theoretical background of the study, its method, the results and discussion and the conclusion.

\section{Review of the literature}

The focus of this section is to present some theoretical background on academic literacy and genre studies, the main tenets of this study. First, prominent aspects of academic literacy are explored, followed by current studies on academic writing in Latin America and Brazil, the location of the present investigation. The third section deals with important features of genre studies. 


\section{Academic Literacy}

Learning in higher education involves several adaptations. Students face new ways of learning, interpreting and organizing knowledge, and academic literacy practices - reading and writing - are central to this process (LEA; STREET, 1998). Lea and Street (1998) point out that academic literacy has been developed from the area of 'new literacy studies' as an attempt to extend the implications of this approach for a different understanding of issues of student learning. Such perspective considers reading and writing as socially situated practices, with a special focus on the power relations that are shaped within those practices (MARINKOVICH et al., 2016).

As a result of that, Lea and Street (1998) argue that educational research into student writing in higher education has fallen into three main perspectives or models: (1) study skills; which assumes that literacy is a set of atomized skills which students have to learn and which are then transferable to other contexts; (2) academic socialization, the focus is on student orientation to learning and interpretation of learning tasks, considering that the task of the tutor/adviser is to induct students into a new 'culture' (academy); and (3) academic literacies, which views the institutions in which academic practices take place as constituted in and as sites of discourse and power, involving a variety of communicative practices, including genres, disciplines and fields. As Street (2004) posits, one important feature of academic literacy is students' "requirement to switch practices between one setting and another, to deploy a repertoire of linguistic practices appropriate to each setting, and to handle the social meanings and identities that each evokes." (p.15).

Considering these features of academic literacy, it is acknowledged in the area the role of teachers and educational institutions in the process of enculturation in this new context (CARLINO, 2013; MARINKOVICH et al., 2016). Recently, Carlino (2013) brought a new conceptualization of academic literacy and pointed out that teachers should help students to engage in contextualized discursive practices, considering that academic literacy changes according to different disciplines and implies a prolonged formation that cannot be achieved from a single subject or in a single educational cycle. Thus, academic literacy is a responsibility of all academic professors and the university as a whole.

Similarly, Cristovão and Vieira (2016) call the attention to the importance of providing different literacy situations to students in order to create learning opportunities, also taking their differences, difficulties and needs into account. Equally important is the investigation of teachers' conceptions about literacy in academic writing, together with the students' own vision on this matter, as a manner to better understand how this process is carried out in a given disciplinary community (LEA; STREET, 1998; BORK et al., 2014; MARINKOVICH et al., 2016).

Although the importance of teaching academic writing is recognized, the way it is 
approached by institutions and professors differs from place to place. Bork et al. (2014) mention that the educational institutions present a variety of approaches and scenarios when dealing with academic writing, and that such differences often take the community history into account. The authors claim that this reality increases the importance of research projects that attempt to understand the current state of the area in different realities, considering the structures, ideologies and policies that rule each country. Bearing in mind this perspective, the following section deals with studies referring to the current state of academic writing in the context of the present investigation, specifically Latin America and Brazil.

\section{Narrowing down: Academic Writing in Latin America}

Students writing and the concern for improving academic writing has led to a growing body of research in Central and South America. As Moritz and Bazerman (2016) posit, the universities in this region departed from a reality in which very few places saw developing student writing as a major responsibility; therefore, there were few curricular structures that gave room to the teaching of writing. This lack of space to academic writing led to the creation of new writing centers and the implementation of new writing coursers to different majors. These changes resulted in the lack of clear home for academic writing instruction and research, since "researchers and teachers were located in different departments, producing research from different perspectives and bringing different approaches to instruction" (MORITZ; BAZERMAN, 2016).

Some actions have been willing to detect and change this scenario. One good example is the project Initiatives of Reading and Writing in Higher Education in Latin America (ILEES), which was created with the objective of mapping pedagogical and research trends regarding what has been happening in the area of reading and writing in higher education in recent years. The project counts with researchers from Brazil, Argentina, Chile, Mexico, Puerto Rico, and Venezuela, and is led by Professor Charles Bazerman, from the University of Santa Barbara, California.

As part of this project, Tapia-Ladino et al. (2016) conducted a study that aimed at understanding the initial milestones, causes, academic activities, theoretical foundations and disciplines involved in the scholarly development of Higher Education reading and writing studies in Latin America. In order to reach this objective, eight academic leaders related to the academic writing field from Argentina, Chile, Colombia, and México were interviewed. Some of their results are interesting to the scope of the present study. Regarding activities, the informants mainly refer to their occupation as researchers, with a relatively low level of participation in teaching writing and subject matters. From the eight participants, only three of them mentioned university teaching. The ones that did, referred mainly to graduate education. 
Also attempting to better understand the writing academic scenario in Latin America, Marinkovich et al. (2016) investigated how literacy in academic writing is addressed in different disciplinary communities at a Chilean university. More specifically, they examined five disciplinary communities - Art, History, Biochemistry, Biology and Mathematics - and attempted to identify the genres that circulate in each of these disciplines in order to determine the way literacy in academic writing is conceived. Their results regarding the teaching of academic writing show that some disciplinary communities - Art, Mathematics and History - recognized the role of the instructor in providing guidance to the production of different genres. Therefore, explicit instruction about academic writing was given to the students. On the other hand, other communities - Biochemistry and Biology - believed that the teaching of writing in higher education is not something they should be responsible for. Marinkovich et al. (2016) do not draw any conclusions regarding this discrepancy.

In Brazil, some studies have also been attempting to understand the role and space of academic writing in higher education. Cristovão and Vieira (2016) conducted an investigation with the objective of identifying and describing the teaching and research initiatives related to reading and writing in higher education in Brazil. The researchers comment that the number of writing centers in Brazil is scarce, with only five universities in the country working on this issue. They also affirm that there are institutional demands for literacy studies, since their results report that students ask for this kind of support when they need to solve their reading or writing problems.

In a similar but more punctual manner, Bork et al. (2014) also mapped the teaching and research initiatives related to reading and writing in higher education in Brazil. The study had thirty-seven respondents - university researchers or professors - that reported twentyone different academic writing activities practiced in their universities. The most mentioned activity was writing courses to freshmen, followed by writing courses to students other than freshmen and other courses that integrate the curriculum. It is interesting to mention that, although it is not the focus of the study, writing courses specific to graduate students were only mentioned by one respondent at one university, which highlights the lack of initiative related to writing courses to graduate students. Bearing in mind the current scenario, both Bork at al., and Cristovão and Vieira (2016) claim for the expansion of academic centers in Brazil and also a reconfiguration that offers courses and workshops related to reading and writing.

One of the existing writing centers in Brazil mentioned by Cristovão and Vieira (2016) is located at USP (Universidade Federal de São Paulo). It is called Academic Literacy Laboratory and aims at meeting the internalization demands through the socialization of academic production in English and French, not only for reading and assimilation of content, but also for publication in those languages (FERREIRA; LOUSADA, 2016). The Lab focuses on graduate and undergraduate students of the university and offers academic writing tutorials, lectures and workshops, consulting, extension courses, and an area of study and reflection 
on academic literacy. As Ferreira and Lousada (2016) affirm, although the project still faces many challenges, its creation can contribute to the training of students and teachers, promoting the integration of different disciplines.

As the studies presented show, there seems to be a consensus in the area regarding the various obstacles academic writing still faces in Latin America (CARLINO, 2013; TAPIALADINO et al., 2016) and Brazil (BORK et al., 2014; CRISTOVÃO; VIEIRA, 2016; FERREIRA; LOUSADA, 2016). This study, therefore, aims at contributing to this diagnosis with the ultimate goal of supporting and grounding future actions and changes in the academic writing context.

AcLits are defined as a process of continuous development on how to interact with different genres, involving particular forms of thinking, being, acting, doing, reading, and writing, which are specific to the academic context. Therefore, exploring how students acquire the genres that circulate in the academic context adds to the understanding of the academic literacy process.

\section{Genre studies}

Genre studies have become extremely popular and achieved considerable status in the last decades. Nowadays, this research area tries to examine different text types produced in different situational contexts by distinct communities with distinct purposes (MEURER; MOTTA-ROTH, 2002). As Bhatia (1996) argues, a genre theory tries to offer a "more dynamic explanation of the way expert users of language manipulate generic conventions to achieve a variety of complex goals" (p. 40). In this sense, it combines the contributions of both sociolinguistic and cognitive perspectives.

Such interest in the use of language to achieve communicative goals ended up taking distinctive paths because of "the theoretical background of the people involved in such research, the nature and extent of investment in the enterprise and also because of the geographical distance between the groups of investigators" (BHATIA, 1996, p. 41). As a result of that, three different major orientations regarding genre studies emerged: New Rhetoric, English for Specific Purposes, and a specific Australian Approach. Although each one of them has its own specificities, they all share a common ground in terms of some genre features: the use of language in conventionalized communicative settings, its dynamism, propensity for innovation, and generic versatility (BHATIA, 1996).

Among these three orientations, English for Specific Purposes (ESP) is the one that focuses on genres produced in academic contexts (SWALES, 1990). Genre here is defined as "a class of communicative events, the members of which share some set of communicative purposes" (SWALES, 1990, p. 58). In consonance with this conceptualization of genre, 
Bawarshi (2010) points out two other inter-related key concepts to this approach: discourse community and communicative purpose. Swales (1990) defines discourse communities as "sociorhetorical networks that form in order to work towards sets of common goals" (p.9). Genres, therefore, comprise a class of communicative events and enable discourse communities to achieve their communicative purposes. Such objectives are "recognized by the expert members of the discourse community" and "shape the schematic structure of the discourse and influence and constrain choice of content and style" (SWALES, 1990, p. 58).

As mentioned before, the ESP tradition of genre studies has stimulated a meaningful mass of work in academic discourse, notably represented by Swales (1990), Dudley-Evans (1994) and Bhatia (1993). Specifically, Swales' (1990) seminal book entitled Genre Analysis investigates the role of language in academic settings and the rhetorical styles employed in such settings. In order to do so, the author offers a theoretical framework that defines the scope and nature of academic discourse through the investigation of the organization patterns of Research Articles - RAs - (MORITZ, 2006). In that book, Swales (1990) focused on the Introduction section, describing the rhetorical moves of this genre that enable it to accomplish its social purpose. In a similar manner, other studies attempted to accomplish a similar goal, but focusing on different RAs sections, such as Method (SWALES; FEAK, 1994), Results (POSTEGUILLO, 1999; BRETT, 1994); Discussion (HOLMES, 1997; DUDLEY-EVANS, 1986), and Conclusion (YANG; ALLISON, 2003; MORITZ, 2006).

Such interest devoted to the academic discourse is also motivated by the fact that students face a new social, cultural and epistemic context once they take the university path. According to Castro, Hernandez and Sanchez (2010), the academic context is unique involving specific practices. Therefore, students entering that community are required to learn the specific genres to act and respond to that social situation: the academic context (MARINKOVICH et al., 2016; FERREIRA; LOUSADA, 2016; CRISTOVÃO; VIEIRA, 2016).

\section{Method}

This section describes the method that was used to investigate how academic writing literacy is approached in sixteen graduate programs of Universidade Federal de Santa Catarina. In order to do so, the instruments of the study will be described, followed by the outline of procedures for data collection and data analysis.

\section{Context and procedures}

The aim of the present study is to investigate how academic writing literacy is approached in graduate programs at Universidade Federal de Santa Catarina. The researcher 
opted for graduate programs considering that students face the challenge of academic writing more often in this modality. It can happen through mandatory readings for courses (i.e academic articles), though the writing of the final project (master thesis or doctoral dissertation), or in many other situations of academic life.

At Universidade Federal de Santa Catarina, there are sixty-six different programs which offer the possibility of obtaining an academic master or doctoral degree. The department responsible for the graduate programs, called "Pró-Reitoria de Pós-graduação", divides the programs in nine different fields: Agricultural Sciences (five programs), Biological Sciences (six programs), Engineering (ten programs), Earth and Exact Sciences (five programs), Multidisciplinary (seven programs), Human Sciences (eight programs), Linguistics and Arts (four programs), Health Sciences (ten programs), and Applied Social Sciences (ten programs).

This study investigated sixteen graduate programs, that is, one quarter of the total number of academic graduate programs. The criteria to choose these programs tried to attend all the nine fields, with one or two samples of each, depending on the total number of program each field has. For example, from Agricultural Sciences, which has only five programs, it was selected only one program as sample; from Health Sciences, which has ten programs, two programs were selected as samples. Regarding the programs themselves, they were selected randomly. The table below specifies the programs chosen for this study:

Table I: Graduate programs selected for this study

\begin{tabular}{|c|c|}
\hline Field & Program \\
\hline Agricultural Sciences & Food Engineering \\
\hline Biological Sciences & Pharmacology \\
Engineering & Ecology \\
Earth and Exact Sciences & Automation Engineering \\
& Mechanical Engineering \\
Multidisciplinary & Mathematics \\
Human Sciences & Chemistry \\
& Scientific and Technological Education \\
Linguistics and Arts & Education \\
Health Sciences & Psychology \\
& Linguistics \\
& Dentistry \\
Applied Social Sciences & Physical Education \\
& Business \\
& Law \\
\hline
\end{tabular}

Source: http://propg.ufsc.br/cap/programas-de-pos-graduacao/

In order to understand how academic writing is approached by each program, the curricular structures of the programs were analyzed, as a manner to search for courses that deal with academic writing. The curricular structures are all available online, on each 
graduate program website.

Therefore, the researchers accessed each program's website and analyzed each curricular structure, more specifically, searching for courses in the curricular structure that explicitly approach academic writing. Once these courses were identified, the researchers then consulted the syllabi ${ }^{3}$ of each course as a manner to better understand how academic writing was treated regarding content - what academic writing content was valued in the courses - and nature - whether the courses were mandatory or not. As a way to complement this inquiry, the researchers also contacted all graduate programs administrative offices in order to confirm the information found on the websites.

Once the samples were selected, the next step was to categorize the information found in the courses' syllabi. The researchers created categories based on the most common features related to academic writing literacy and tried to group them together. The categories created were: (1) Academic English: How to write academic articles in English: Clarity, objectivity, conciseness, fluidity, rhythm, style. Most common English mistakes made by Brazilian Portuguese speakers; (2) Cover Letter: How to write a journal cover letter; (3) Writing Techniques: General scientific writing techniques: text structure, what should be avoided, techniques to make the text more concise and objective; (4) Academic Genres Sections: Introduction, review of literature, methodology, results, discussion, figures and tables: what should be stated, what cannot be missing and what to avoid in each of these sections; (5) Abstract: How to write an abstract, choice of keywords; (6) References and Citations: Enable students to use softwares of organization and analysis of references and citations, how to structure references and citations, $\mathrm{ABNT}^{4}$ rules; (7) Research problem/Objectives/Hypothesis: Identification of the topic and research questions. Delimitation of the problem, objectives and hypothesis.

Once the courses were organized according to the categories, the researchers then analyzed the results aiming to identify the most common academic writing features addressed by the graduate programs, which would lead to a panorama of this topic situation at Universidade Federal de Santa Catarina. The results were also compared to previous literature addressed in the review of literature section presented above.

\section{Results and discussion}

In order to better understand how academic writing literacy is approached in sixteen graduate programs at Universidade Federal de Santa Catarina, the specific questions of this study are addressed now.

\footnotetext{
${ }^{3}$ In Brazil, courses' syllabi are known as "planos de ensino", the genre analyzed in this study.

${ }^{4}$ Stands for "Associação Brasileira de Normas Técnicas". It is the Brazilian Association responsible for standardizing the techniques in scientific production.
} 
Is there a specific academic writing course? If so, what is its nature (elective, mandatory, aiming master's/doctoral students)?

From the sixteen graduate programs investigated, eight programs do not offer any courses related to academic writing. They are: Food Engineering, Pharmacology, Mathematics, Chemistry, Scientific and Technological Education, Education, Linguistics, and Economy. They represent $50 \%$ of the samples investigated.

It is also interesting to mention that, from the nine fields of graduate programs at Universidade Federal de Santa Catarina (table I), only two of them - Engineering and Health Science - approach academic writing in all of their specific programs investigated by this study (Automation Engineering / Mechanical Engineering and Dentistry / Physical Education). The other seven fields have at least one program that does not deal with academic writing at all. However, considering the small sample of this study, it is not possible to draw any conclusions regarding the relation between the field of graduate programs and the importance given to academic writing, that is, if a specific field gives more or less attention to this topic. Such predominant lack of pattern among fields is in accordance with Bazerman and Moritz's (2016) comments on the current situation of Academic Writing in Latin America: few curricular structures give place to the teaching of writing and there is a lack of clear home for academic writing instruction and research.

The other eight programs investigated - Ecology, Automation Engineering, Mechanical Engineering, Psychology, Dentistry, Physical Education, Business, and Law - have at least one course designated to or containing academic writing. These courses and their characteristics are listed below:

Table II: List of programs and courses that deal with Academic Writing

\begin{tabular}{|c|c|c|c|c|c|}
\hline $\begin{array}{l}\text { Graduate } \\
\text { Program }\end{array}$ & Course & Compulsory & Elective & Master's & Doctoral \\
\hline Ecology & $\begin{array}{c}\text { - Capacitação na Elaboração de Artigos } \\
\text { Científicos na Língua Inglesa } \\
\text { - Comunicação Científica }\end{array}$ & & $\begin{array}{l}x \\
x\end{array}$ & $\begin{array}{l}X \\
X\end{array}$ & $\begin{array}{l}X \\
X\end{array}$ \\
\hline $\begin{array}{l}\text { Automation } \\
\text { Engineering }\end{array}$ & - Metodologia Científica & $x$ & & $x$ & $x$ \\
\hline $\begin{array}{l}\text { Mechanical } \\
\text { Engineering }\end{array}$ & - Escrita científica em Inglês & & $x$ & $x$ & $x$ \\
\hline Psychology & $\begin{array}{l}\text { - Métodos e Procedimentos de Pesquisa em } \\
\text { Psicologia } \\
\text { - Tópicos especiais em Psicologia das } \\
\text { Organizações e do Trabalho II: Métodos e }\end{array}$ & $X$ & $x$ & $x$ & $x$ \\
\hline
\end{tabular}




\begin{tabular}{|c|c|c|c|c|c|}
\hline & técnicas de revisão de literatura & & & & \\
\hline Dentistry & $\begin{array}{l}\text { - Metodologia da Pesquisa Científica } \\
\text { - Métodos Qualitativos de Investigação } \\
\text { - Oficina de Redação Cientifica }\end{array}$ & $X$ & $\begin{array}{l}X \\
X\end{array}$ & $\begin{array}{l}X \\
X \\
X\end{array}$ & $\begin{array}{l}x \\
X\end{array}$ \\
\hline $\begin{array}{l}\text { Physical } \\
\text { Education }\end{array}$ & $\begin{array}{l}\text { - Produção e Veiculação do Conhecimento em } \\
\text { Educação Física } \\
\text { - Metodologia da Pesquisa em Educação Física }\end{array}$ & $x$ & & $x$ & \\
\hline Business & $\begin{array}{l}\text { - Tópicos Especiais em Administração } \\
\text { Universitária 2: Projeto de Qualificação }\end{array}$ & & $x$ & $x$ & $\mathrm{x}$ \\
\hline Law & $\begin{array}{l}\text { - Fundamentos e Metodologia da Pesquisa em } \\
\text { Direito } \\
\text { - Métodos e Metodologias Aplicados ao } \\
\text { Projeto de Tese }\end{array}$ & $X$ & $X$ & $\mathrm{X}$ & $\mathrm{x}$ \\
\hline
\end{tabular}

Source: Graduate programs' websites

Among all the programs investigated, the researcher found fourteen courses dealing with academic writing. Most of them (eight) are elective courses, that is, they are not compulsory to complete the graduation or degree. The six others are part of the compulsory curricula, that is, students must pass in order to meet the regulations to be eligible to graduate. This scenario is not in accordance with some authors' recommendation (CARLINO, 2013; CRISTOVÃO; VIEIRA, 2016), who emphasize the importance of providing different academic literacy situations to students in order to take their difficulties and needs into account, and create learning opportunities.

Regarding the target audience, thirteen courses aim at master students, and ten courses aim at doctoral students. This data might indicate that doctoral students are more experienced in academic writing, what justifies the lower number of courses. In accordance with this idea, many authors claim (MARINKOVICH et al., 2016; FERREIRA; LOUSADA, 2016; CRISTOVÃO; VIEIRA, 2016) that students first face the need for academic literacy when they have their first contact with the academic context. That is when the need to learn new writing strategies to successfully participate in this higher education context is emphasized. However, academic literacy implies a prolonged education that cannot be achieved from a single subject or in a single educational cycle (CARLINO, 2013), what justifies the need for courses in doctoral programs as well.

What aspects of academic writing are valued by the programs/courses?

The syllabi of all fourteen courses that deal with academic writing were analyzed and divided into the categories presented in the Method section. The results were the following: 
Table III: Aspects of academic writing approached by the courses

\begin{tabular}{|c|c|c|}
\hline Topic & Graduate Program & Course \\
\hline \multirow{2}{*}{$\begin{array}{l}\text { Academic } \\
\text { English }\end{array}$} & Ecology & $\begin{array}{c}\text { Capacitação na Elaboração de Artigos Científicos na } \\
\text { Língua Inglesa }\end{array}$ \\
\hline & Mechanical Engineering & Escrita Científica em Inglês \\
\hline \multirow[t]{2}{*}{ Cover Letter } & \multirow[t]{2}{*}{ Ecology } & $\begin{array}{c}\text { Capacitação na Elaboração de Artigos Científicos na } \\
\text { Língua Inglesa }\end{array}$ \\
\hline & & Comunicação Científica \\
\hline $\begin{array}{c}\text { Writing } \\
\text { Techniques }\end{array}$ & Ecology & Comunicação Científica \\
\hline \multirow{10}{*}{$\begin{array}{l}\text { Academic } \\
\text { Genres Sections }\end{array}$} & Ecology & $\begin{array}{c}\text { Capacitação na Elaboração de Artigos Científicos na } \\
\text { Língua Inglesa }\end{array}$ \\
\hline & Ecology & Comunicação Científica \\
\hline & Automation Engineering & Metodologia Científica \\
\hline & Mechanical Engineering & Escrita Científica em Inglês \\
\hline & Psychology & $\begin{array}{c}\text { Tópicos especiais em Psicologia das Organizações e } \\
\text { do Trabalho II: Métodos e técnicas de revisão de } \\
\text { literatura }\end{array}$ \\
\hline & Psychology & $\begin{array}{l}\text { Métodos e Procedimentos de Pesquisa em } \\
\text { Psicologia }\end{array}$ \\
\hline & Physical Education & $\begin{array}{c}\text { Produção e Veiculação do Conhecimento em } \\
\text { Educação Física }\end{array}$ \\
\hline & Business & $\begin{array}{l}\text { Tópicos Especiais em Administração Universitária 2: } \\
\text { Projeto de Qualificação }\end{array}$ \\
\hline & & Fundamentos e Metodologia da Pesquisa em Direito \\
\hline & Law & $\begin{array}{c}\text { Métodos e Metodologias Aplicados ao Projeto de } \\
\text { Tese }\end{array}$ \\
\hline \multirow[b]{2}{*}{ Abstract } & Ecology & Comunicação Científica \\
\hline & Physical Education & $\begin{array}{l}\text { Produção e Veiculação do Conhecimento em } \\
\text { Educação Física }\end{array}$ \\
\hline \multirow{4}{*}{$\begin{array}{l}\text { References and } \\
\text { Citations }\end{array}$} & Psychology & $\begin{array}{c}\text { Tópicos especiais em Psicologia das Organizações e } \\
\text { do Trabalho II: Métodos e técnicas de revisão de } \\
\text { literatura }\end{array}$ \\
\hline & Physical Education & $\begin{array}{l}\text { Produção e Veiculação do Conhecimento em } \\
\text { Educação Física }\end{array}$ \\
\hline & & Fundamentos e Metodologia da Pesquisa em Direito \\
\hline & Law & $\begin{array}{c}\text { Métodos e Metodologias Aplicados ao Projeto de } \\
\text { Tese }\end{array}$ \\
\hline \multirow{4}{*}{$\begin{array}{c}\text { Research } \\
\text { problem / } \\
\text { Objectives / } \\
\text { Hypothesis }\end{array}$} & Automation Engineering & Metodologia Científica \\
\hline & Psychology & $\begin{array}{l}\text { Métodos e Procedimentos de Pesquisa em } \\
\text { Psicologia }\end{array}$ \\
\hline & Physical Education & $\begin{array}{l}\text { Produção e Veiculação do Conhecimento em } \\
\text { Educação Física }\end{array}$ \\
\hline & Law & Fundamentos e Metodologia da Pesquisa em Direito \\
\hline
\end{tabular}

As the table shows, there is no pattern in the courses' content. That is, each course 
and each program deals with academic writing in a different manner, focusing on different aspects. It is important to mention that there is no writing center at Universidade Federal de Santa Catarina to standardize the academic writing activities in the graduate programs, which reflects on each graduate program dealing with academic writing in a different way. It again corroborates Bazerman and Moritz's (2016) description of the current scenario of Higher Education academic writing in Latin America, that is, there is no clear home for academic writing instruction at the universities.

Even so, three academic writing topics seem to stand out. Two of them have a significant number of courses: four out of fourteen. They are References and Citations and Research problem/Objectives/Hypothesis. The second category shows a huge discrepancy when compared to other ones: most graduate programs investigated deal with this aspect, totalizing ten out fourteen courses. This category, Academic genres sections, deals exactly with the perspective taken by the genre approach English for Specific Purposes, which is many authors' topic of investigation (DUDLEY-EVANS, 1986; SWALES, 1990; BRETT, 1994; SWALES; FEAK, 1994; HOLMES, 1997; POSTEGUILLO, 1999; YANG; ALLISON, 2003; MORITZ, 2006). This topic works with the content of each academic section (Introduction, Review of Literature, Method, Results, Discussion, and Conclusion), more specifically, what should be stated, what cannot be missing and what to avoid in each of these sections.

Judging by the results of this investigation, it seems that the academic writing courses of graduate programs at UFSC prioritize the structural aspects of academic writing, that is, its sections and respective content. Secondly, some attention has also been given to methodological and theoretical aspects, such as definition of scientific knowledge, research methods, data collection procedures, delimitation of the problem, objectives and hypothesis, and how to write citations and references. Lastly, it seems that little attention has been paid to the writing itself, that is, techniques about how to improve academic writing, such as tips on clarity, objectivity, conciseness, fluidity, rhythm, style, among others. Such scenario is not a surprise considering that there is no writing center at Universidade Federal de Santa Catarina, and therefore, the specific courses on academic writing and professors who are experts on that matter do not reach every graduate program. The discussion of this issue, however, is not part of the scope of this study, which main goal was to give a panorama of the current scenario of academic writing literacy at Universidade Federal de Santa Catarina.

\section{Conclusion}

Given the importance of the development of academic writing literacy in higher education in Latin America (RUSSEL, 1991; BAZERMAN; MORITZ, 2016; MARINKOVICH et al., 2016), this paper aimed at investigating how academic writing literacy is approached in graduate programs at Universidade Federal de Santa Catarina. In order to reach this 
objective, one quarter (sixteen) of the university graduate programs were explored as a manner to find courses dealing with academic writing literacy.

First of all, the results showed that there is no clear home for academic writing instruction at UFSC, that is, reading and writing is a disciplinary space addressed differently by each program or area of knowledge. Moreover, the results also showed that academic writing does not seem to be considered a major concern in the graduate programs of UFSC, since only fifty percent of the programs investigated make available courses on that topic. It is also interesting to mention that no pattern was found between the fields and the content of academic writing courses. From the other eight programs that work with academic writing, fourteen courses were found, most of them (eight) being elective and aiming at master students. Again, these results show that academic writing does not seem to be considered a major concern in this university, considering that exposure and instruction on that is considered paramount to successfully participate in this discourse community (CARLINO, 2013; CRISTOVÃO; VIEIRA, 2016).

Regarding the aspects valued by the fourteen courses, one aspect seems to stand out: the structural aspects of academic writing, being reflected by instruction on Academic genres sections. This aspect is related to one major concern of the genre approach English for Specific Purposes, which focuses on academic writing and tries to identify rhetorical patterns in each of the Research Article sections (SWALES, 1990). One second aspect approached by the courses focuses on delimitation of the problem, objectives and hypothesis, and how to write citations and references. Little attention is given to other aspects such as writing techniques themselves.

As mentioned before, higher education writing studies in Latin America has been gaining space in the current research scenario. As a proof of that, there is the creation of research projects such as ILEES (Initiatives of Reading and Writing in Higher Education in Latin America, which has been focusing on either undergraduate or gradute levels of education) and also many studies attempting to map and establish a diagnosis of the current panorama of academic writing in Latin America universities (BORK et al., 2014; BAZERMAN et al., 2016; MARINKOVICH et al., 2016; TAPIA-LADINO et al., 2016; CRISTOVÃO; VIEIRA, 2016). This study attempted to help in the establishment of this panorama by investigating the reality of academic writing in graduate programs of a Brazilian university. This piece of research, therefore, can help future initiatives related to the expansion of academic writing centers in Brazil and also in the reconfiguration of courses related to reading and writing, following some authors' claim (BORK et al., 2014; CRISTOVÃO; VIEIRA, 2016).

Finally, as suggestions for future research, it would be interesting to investigate not only some, but all graduate courses at UFSC in order to have a broader panorama and be able to draw more solid conclusions. Also, it would be valid to interview the graduate students to better understand their view and needs related to academic writing and whether the courses available by the program fulfill such needs. Lastly, interviews with the 
coordination and professors of the graduate programs could contribute to the understanding of how academic writing is viewed and approached in the university.

\section{References}

BAWARSHI, A. S.; MARY J. R. Genre: An Introduction to History, Theory, Research, and Pedagogy. West Lafayette: Parlor, 2010.

BAZERMAN, C.; MORITZ, M.E.W. Higher Education Writing in Latin America. Ilha do Desterro, v. 69, n. 3, p. 9-11, 2016. https://doi.org/10.5007/2175-8026.2016v69n3p9

BAZERMAN, C.; ÁVILA REYES, N.; BORK, A. V.; CORRÊA, F.; CRISTOVÃO, V. L.; TAPIA LADINO, M.; NARVÁEZ, E. Intellectual orientations of studies of higher education writing in Latin America. In PLANE, S; BAZERMAN, C.; DONAHUE, C.; RONDELLI, F. (Eds.). Recherches en écriture: regards pluriels. Nancy: Université de Lorraine, 2014.

BATHIA, V. K. A. Analysing genres: language use in professional settings. New York: Longman, 1993.

BHATIA, V. K. Methodologial Issues in Genre Analysis. Journal of Linguistics, v. 16, n. 1-26, 1996.

BORK, A. V.; BAZERMAN, C.; CORREA, F.; CRISTOVÃO, V. L. Mapeamento das iniciativas de escrita em língua materna na educação superior: resultados preliminares. Revista Prolíngua, v. 9, n. 1, p. 2-14, 2014.

BRETT, P. A genre analysis of the results section of sociology articles. English for Specific Purposes, v. 13, p. 47-59, 1994. https://doi.org/10.1016/0889-4906(94)90024-8

CARLINO, P. Escribir, leer y aprender en la universidad: Una introducción a la alfabetización académica. Buenos Aires: Fondo de Cultura Económica, 2005.

CARLINO, P. Alfabetización académica diez años después. Revista Mexicana de Investigación Educativa, v. 18, n. 57, p. 55-381, 2013.

CASTRO, M. C.; HERNÁNDEZ, L. A.; SÁNCHEZ, M. El ensayo como género académico: una aproximación a las prácticas de escritura en la universidad pública mexicana. In: PARODI, G. (Ed.). Alfabetización académica y profesional en el siglo XXI. Leer y escribir desde las disciplinas. Santiago de Chile: Ariel, 2010. p. 49-70.

CRISTOVÃO, V. L. L.; VIEIRA, I. R. Letramentos em Língua Portuguesa e Inglesa na Educação Superior Brasileira: Marcos e Perspectivas. Ilha do Desterro, v. 69, n. 3, p. 209-211, 2016. https://doi.org/10.5007/2175-8026.2016v69n3p209

DUDLEY-EVANS, T. Genre Analysis: an investigation of the introductions and discussions sections of MSC dissertations. In: COULTHARD, M. (Ed.). Talking about text. Birmingham: 1986. p. 128-145.

DUDLEY-EVANS, T. Genre analysis: An approach to text analysis for ESP. In: COULTHARD, M. (Ed.). Advances in written text analysis. London: Routledge, 1994. p. 219-228. 
FERREIRA, M. M.; LOUSADA, E. G. Ações do laboratório de letramento acadêmico da Universidade de São Paulo: Promovendo a escrita acadêmica na graduação e na pósgraduação. Ilha do Desterro, v. 69, n. 3, p. 125-138, 2016. https://doi.org/10.5007/2175$\underline{8026.2016 v 69 n 3 p 125}$

HOLMES, R. (1997). Genre analysis, and the social sciences: An investigation of the structure of RA Discussion sections in three disciplines. English for Specific Purposes, v. 16, n. 4, p. 321337, 1997. https://doi.org/10.1016/S0889-4906(96)00038-5

LEA, M. R.; STREET, B. V. Student writing in higher education: An academic literacies approach. Studies in higher education, v. 23, n. 2, p, 157-172, 1998. https://doi.org/10.1080/03075079812331380364

MARCUSCHI, L. A. Gêneros textuais: definição e funcionalidade. In: DIONÍSIO, A. et al. Gêneros textuais e ensino. Rio de Janeiro: Lucerna, 2002.

MARINKOVICH, J; VELÁSQUEZ, M.; CÓRDOVA, A.; CID, C. Academic Literacy and Genres in University Learning Communities. Ilha do Desterro, v. 69, n. 3, p. 95-113, 2016. https://doi.org/10.5007/2175-8026.2016v69n3p95

MEURER, J. L.; MOTTA-ROTH, D. Gêneros textuais: práticas discursivas. Bauru, São Paulo: Edusc, 2002.

MORITZ, M. E. W. A Contrastive Genre Study of Conclusions as Components of Research Articles Across PL1, EL1 and EL2. (Doctoral dissertation). Retrieved from Universidade Federal de Santa Catarina Bibliography Database, Florianópolis, 2006.

NAVARRO, F.; ÁVILA REYES, N.; TAPIA LADINO, M.; LOPEZ CRISTOVÃO, V. L.; MORITZ, M. E. W.; NARVÁEZ CARDONA, E.; BAZERMAN, C. Panorama histórico y contrastivo de los estudios sobre lectura y escritura en educación superior publicados en América Latina. Revista Signos, v. 49, p. 100-126, special issue on academic literacy, 2016. https://doi.org/10.4067/S0718$\underline{09342016000400006}$

POSTEGUILLO, S. The schematic structure of computer science research articles. English for Specific Purposes, v. 18, n. 2, p. 139-160, 1999. https://doi.org/10.1016/S08894906(98)00001-5

PROPG, UFSC. Disponível em: http://propg.ufsc.br/cap/programas-de-pos-graduacao/ Acesso em: 01 de julho de 2019.

RUSSEL, D. Writing in the Academic Disciplines, 1870-1990: A curricular history. Carbondale, IL: Southern Illinois UP, 1991.

STREET, B. Academic literacies and the 'new orders': implications for research and practice in student writing in higher education. Learning and Teaching in the Social Sciences, v. 1, n. 1, p. 9-20, 2004. https://doi.org/10.1386/ltss.1.1.9/0

SWALES, J. M. Genre analysis: English in academic and research settings. Cambridge: Cambridge University Press, 1990.

SWALES, J. M.; FEAK, C. B. Academic writing for graduate students. Ann Arbor, MI: The University of Michigan Press, 1994.

TAPIA-LADINO, M; REYES, N.A.; NAVARRO, F.; BAZERMAN, C. Milestones, Disciplines and the Future of Initiatives of Reading and Writing in Higher Education: An analysis from key 
scholars in the field in Latin America. Ilha do Desterro, v. 69, n. 3, p. 190-208, 2016. https://doi.org/10.5007/2175-8026.2016v69n3p189

YANG, R.; ALLISON, D. Research articles in applied linguistics: moving from results to conclusions. English for Specific Purposes, v. 22, p. 365-385, 2003. https://doi.org/10.1016/S0889-4906(02)00026-1

Recebido em: 20/03/2019

Aceito em: 17/07/2019 